\title{
The HIV-1 Epidemic: Low- to Middle-Income Countries
}

\author{
Yiming Shao ${ }^{1}$ and Carolyn Williamson ${ }^{2}$ \\ ${ }^{1}$ The State Key Laboratory for Infectious Disease Control and Prevention, National Center for AIDS/STD \\ Control and Prevention, Chinese Center for Disease Control and Prevention, Changping District, \\ Beijing 102206, China \\ ${ }^{2}$ Institute of Infectious Diseases and Molecular Medicine, Division of Medical Virology, University \\ of Cape Town and National Health Laboratory Service, 7925 South Africa \\ Correspondence: carolyn.williamson@uct.ac.za
}

Low- to middle-income countries bear the overwhelming burden of the human immunodeficiency virus type 1 (HIV-1) epidemic in terms of the numbers of their citizens living with HIV/AIDS (acquired immunodeficiency syndrome), the high degrees of viral diversity often involving multiple HIV-1 clades circulating within their populations, and the social and economic factors that compromise current control measures. Distinct epidemics have emerged in different geographical areas. These epidemics differ in their severity, the population groups they affect, their associated risk behaviors, and the viral strains that drive them. In addition to inflicting great human cost, the high burden of HIV infection has a major impact on the social and economic development of many low- to middle-income countries. Furthermore, the high degrees of viral diversity associated with multiclade HIV epidemics impacts viral diagnosis and pathogenicity and treatment and poses daunting challenges for effective vaccine development.

\begin{abstract}
$A^{\text {lthough the first cases of acquired immuno- }}$ Adeficiency syndrome (AIDS) were identified in North America in 1981, molecular epidemiology studies have placed the geographical origin of HIV-1 in west-central equatorial Africa (Keele et al. 2006). Today, Africa still shoulders the greatest burden of the epidemic, harboring $>68 \%$ of all infections despite accommodating only $13 \%$ of the world's population (UNAIDS 2010). The last five years have seen the epidemic reaching a peak in Africa, Latin America, and the Caribbean, and most parts of Asia. However,
\end{abstract}

rates of transmission are still rising in Eastern Europe and Central Asia (UNAIDS 2010). In this work, we describe what is known about the emergence of HIV-1 in low- to middleincome countries, focusing specifically on the countries in sub-Saharan Africa, Asia, Latin America, and the Caribbean that are most affected by the epidemic. We provide an overview of the current status of the epidemic, its molecular epidemiology, and the impact of HIV diversity on disease progression, treatment, and vaccine development.

Editors: Frederic D. Bushman, Gary J. Nabel, and Ronald Swanstrom

Additional Perspectives on HIV available at www.perspectivesinmedicine.org

Copyright (C) 2012 Cold Spring Harbor Laboratory Press; all rights reserved; doi: 10.1101/cshperspect.a007187

Cite this article as Cold Spring Harb Perspect Med 2012;2:a007187 


\section{EPIDEMIOLOGICAL HISTORY}

The first cases of AIDS in Africa were described in the early 1980s where it affected heterosexual populations in a band of equatorial countries including Zaire (now Democratic Republic of Congo), Rwanda, and Uganda (Piot et al. 1984; van de Perre et al. 1984; Serwadda et al. 1985). It was initially known as "slim disease" because it was associated with diarrhea and weight loss. The spread of HIV-1 to southern African countries occurred later where detection in the general population of, for example, South Africa was only observed in the late 1980s (Gouws et al. 2010).

Whereas the epidemic in Africa has always been driven by heterosexual transmission, in other regions such as Latin America and the Caribbean, the HIV epidemic was also associated with injection drug use (IDU) and men who have sex with men (MSM). In these regions, the HIV epidemic started in the late 1970s and early 1980s. By the year 2000, the Caribbean had the second highest prevalence of HIV-1-infected adult population outside sub-Saharan Africa (PAHO, WHO, UNAIDS 2001).

In Asia, HIV/AIDS was first reported in Thailand, India, and China around the midto late 1980s (Phanuphak et al. 1985; Zeng et al. 1986; Simoes et al. 1987). Since the early 1990s, HIV prevalences in excess of $10 \%$ were documented among female sex workers (FSW) in Thailand and India, as well as among IDUs in countries near the "golden triangle" region (where the borders of Thailand, Myanmar, and Laos meet) (Ma et al. 1990; Estebanez et al. 1993; Dore et al. 1996; Crofts et al. 1998; WHO 1998). The epidemic then spread to more countries and populations in Asia through IDU, heterosexual transmission, and, at a later time, through MSM contacts, as well as mother-to-child transmission.

\section{CURRENT STATUS}

The brunt of the epidemic globally is carried by the low- to middle-income countries, which provide the virus with a fertile environment to spread owing to a combination of factors including poor socioeconomic conditions, lack of access to health care, economic or political displacement of communities, and, to a certain extent, cultural practices and gender inequalities. The highest HIV prevalence in the adult population aged $15-49 \mathrm{yr}$ is within sub-Saharan Africa (5\%), followed by the Caribbean (1\%), Eastern Europe and Central Asia $(0.8 \%)$, Central and South America $(0.5 \%)$, South and Southeast Asia $(0.3 \%)$, and East Asia (0.1\%) (Fig. 1 and Table 1) (UNAIDS 2010). Staggeringly, $91 \%$ of the world's total HIV-1-infected population, numbering 30 million people (UNAIDS 2010), resided in low- to middle-income countries in 2009. Being hit the hardest by the epidemic is sub-Saharan Africa, which harbors about three-quarters of the world's HIV-1-infected individuals from lowand middle-income countries and more than two-thirds of the world's total (Table 1). Other regions with high HIV/AIDS burdens include South and Southeast Asia, Eastern Europe and Central Asia, and Central and South America, which, respectively, account for approximately $12 \%, 4 \%$, and $4 \%$ of the world's HIV-1-infected individuals (Table 1).

Low- to middle-income countries also carry the heaviest burden of drug use-related HIV infections. The three regions with both the highest numbers and the highest prevalence of HIV-positive IDUs are all low- to middleincome regions: Latin America, with 580,000 HIV-infected IDUs (a prevalence of 29\%), Eastern Europe with 940,000 HIV-infected IDUs (a prevalence of 27\%), and East and Southeast Asia with 661,000 HIV-infected IDUs (a prevalence of 17\%) (Table 2). These associations suggest that the fight against drug trafficking and abuse in these regions is inextricably linked with the fight against HIV.

\section{Trends in Africa}

The epidemic in sub-Saharan Africa is devastating. In 2009, approximately 22.5 million Africans were living with HIV-1, with the worst affected region being southern Africa where about one-third of the world's HIV-infected 

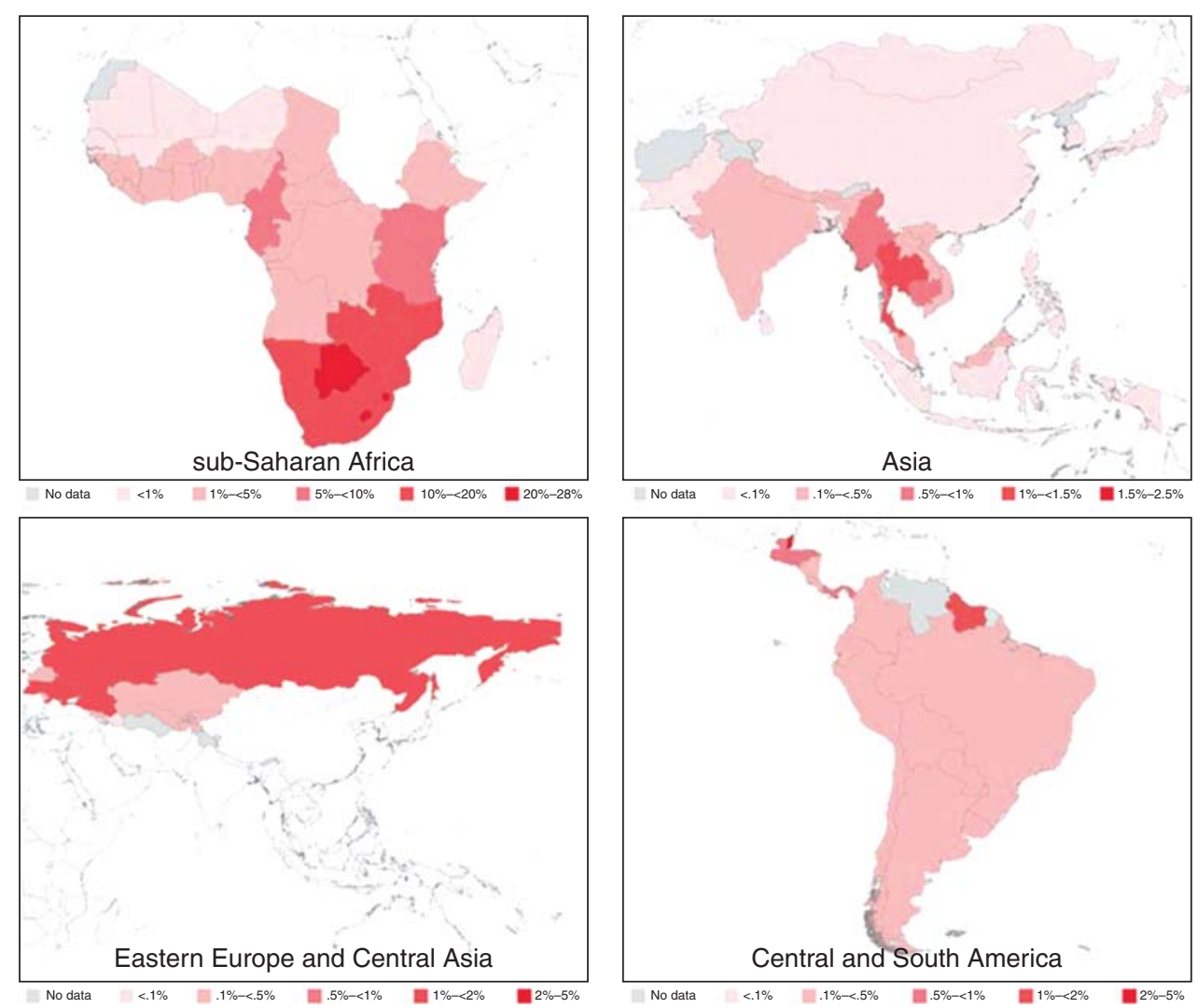

Figure 1. Estimated HIV prevalences in 2009 among adults aged 15-49 years old in sub-Saharan Africa, Asia, Eastern Europe, and Central Asia. (Source: UNAIDS.)

people reside (UNAIDS 2010). There are huge country-to-country variations in the severity of the epidemic. Whereas most southern African countries (Zambia, Zimbabwe, Malawi, Mozambique, Namibia, Botswana, Lesotho, South Africa, and Swaziland) have an adult $(15-49 \mathrm{yr})$ prevalence of $>10 \%$, those in East and Central Africa (Uganda, Kenya, Tanzania, Cameroon, and Rwanda) have less severe epidemics, with adult HIV prevalences ranging between 5\% and 10\%. Most West African countries have adult prevalences below $1 \%$. Although the worst affected country globally is Swaziland, where approximately $26 \%$ of adults are infected with the virus, South Africa is the country with the greatest number of individuals living with HIV: an estimated 5.6 million. In the countries worst affected by the epidemic, life expectancy has been reduced by as much as 20 years and there has been a concomitant reduction in income and an increase in household poverty (UNAIDS 2010).

The social, economic, and political factors responsible for the widespread epidemic in southern Africa include poverty, poor social and health infrastructure, lack of education, political and social instability, the low status of women, and sexual violence, as well as lack of political commitment, slow control response, and ineffective preventive measures during critical periods of HIV epidemic in the region. There is no single factor that accounts for the high HIV prevalences observed in certain countries in Africa. Behavioral factors are likely to have contributed, including the number of casual sexual partners, condom usage, age of sexual debut, intergenerational sex, concurrency, and sexual networks (Gregson et al. 2002; Abdool 
Y. Shao and C. Williamson

Table 1. HIV/AIDS statistics for selected regions in 2009

\begin{tabular}{|c|c|c|c|c|}
\hline Regions & $\begin{array}{l}\text { Estimated people } \\
\text { living with HIV } \\
\text { (percent of world } \\
\text { total) }\end{array}$ & $\begin{array}{c}\text { People newly } \\
\text { infected with HIV }\end{array}$ & $\begin{array}{c}\text { Estimated percent } \\
\text { adult prevalence } \\
\qquad(15-49)\end{array}$ & $\begin{array}{c}\text { Estimated AIDS-related } \\
\text { deaths ( percent of } \\
\text { world total) }\end{array}$ \\
\hline $\begin{array}{l}\text { Sub-Saharan } \\
\text { Africa }\end{array}$ & 22.5 million $(68 \%)$ & 1.8 million $(69 \%)$ & 5.0 & 1.3 million $(72 \%)$ \\
\hline $\begin{array}{l}\text { South and } \\
\text { Southeast Asia }\end{array}$ & 4.1 million $(12 \%)$ & $270,000(10 \%)$ & 0.3 & $260,000(14 \%)$ \\
\hline East Asia & $770,000(2.3 \%)$ & $82,000(3 \%)$ & 0.1 & $36,000(2.0 \%)$ \\
\hline $\begin{array}{l}\text { Eastern Europe } \\
\text { and Central } \\
\text { Asia }\end{array}$ & 1.4 million $(4.2 \%)$ & $130,000(5 \%)$ & 0.8 & $76,000(4.2 \%)$ \\
\hline Caribbean & $240,000(0.7 \%)$ & $17,000(0.7 \%)$ & 1.0 & $12,000(0.7 \%)$ \\
\hline $\begin{array}{l}\text { Central and South } \\
\text { America }\end{array}$ & 1.4 million $(4.2 \%)$ & $92,000(3.5 \%)$ & 0.5 & $58,000(3.2 \%)$ \\
\hline Subtotal & 30.41 million $(92 \%)$ & 2.39 million $(92 \%)$ & & 1.74 million $(97 \%)$ \\
\hline World total & 33.3 million & 2.6 million & & 1.8 million \\
\hline
\end{tabular}

Data from UNAIDS (2010), with modification.

Karim et al 2010; UNAIDS 2010; Ott et al. 2011; Steffenson et al. 2011). Differences in male circumcision practices may also play a role as circumcision has been associated with a $\sim 60 \%$ reduction in risk of infection, and lack of circumcision in some communities may put these men at increased risk of infection (Auvert et al. 2005; Gray et al. 2007). The epidemic in Africa is fueled by genetically diverse viral genotypes, which may differ in terms of pathogenicity and rates of transmission (Kaleebu et al. 2002). Early HIV infection is associated with high viral loads, and in a region in southern Africa, nearly $40 \%$ of transmissions were attributed to this phase of infection (Powers et al. 2011). Lastly, host genetics affects susceptibility to infection (Pereyra et al. 2010). It is likely that a combination of these factors has contributed to the varying intensity of the epidemic in Africa; however, the relative contribution that each of these factors makes is unknown.

The Africa HIV/AIDS epidemic appears to have peaked in the mid-1990s, and over the last 10 years there has been a decrease in the number of new infections (estimated to be 1.8 million in 2009 compared with 2.2 million in 1999) (UNAIDS 2010). Although this decrease is thought to be attributable, in part, to the natural course of the HIV epidemic, it is probably also attributable to significant changes in human behavior. Specifically, in 13 sub-Saharan African countries, the age of sexual debut and condom usage has significantly increased, and the number of sexual partners has significantly decreased (UNAIDS 2010). Despite declining infection rates, the massive increase in access to antiretrovirals is expected to result in people living longer with HIV and consequently, to an increase in the number of HIV-1-infected individuals.

In Africa, women are disproportionally affected by the epidemic and accordingly account for $60 \%$ of infections. Women are eight times more likely to become infected than their male counterparts (Powers et al. 2008). Although part of this discrepancy is attributable to women being biologically more susceptible to infection, women are also more vulnerable to infection owing to both gender-associated violence and sociocultural factors that restrict their economic empowerment and access to health care. Along with large numbers of HIV-1-infected women come large numbers of infected babies: There are currently 2.3 million children living with HIV in sub-Saharan Africa. 
The HIV-1 Epidemic: Low- to Middle-Income Countries

Table 2. Regional and global estimates of the number of IDUs and the number of HIV-positive IDUs in 2007

\begin{tabular}{|c|c|c|c|c|c|}
\hline \multirow[b]{2}{*}{ Region } & \multicolumn{2}{|c|}{$\begin{array}{l}\text { Estimated number of } \\
\text { IDUs }\end{array}$} & \multicolumn{2}{|c|}{$\begin{array}{l}\text { Estimated number of } \\
\text { HIV-positive IDUs }\end{array}$} & \multirow{2}{*}{$\begin{array}{c}\text { Estimated HIV } \\
\text { prevalence of IDUs } \\
\%\end{array}$} \\
\hline & Median number & $\%$ & Median number & $\%$ & \\
\hline Latin America & $2,018,000$ & 13 & 580,500 & 19 & 29 \\
\hline Eastern Europe & $3,476,500$ & 22 & 940,000 & 31 & 27 \\
\hline East and Southeast Asia & $3,957,500$ & 25 & 661,000 & 22 & 17 \\
\hline Canada and USA & $2,270,500$ & 14 & 347,000 & 12 & 15 \\
\hline South Asia & 569,500 & 3.6 & 74,500 & 2.5 & 13 \\
\hline Caribbean & 186,000 & 1.2 & 24,000 & 0.8 & 13 \\
\hline Sub-Saharan Africa & $1,778,500$ & 11 & 221,000 & 7.4 & 12 \\
\hline Central Asia & 247,500 & 1.6 & 29,000 & 1.0 & 12 \\
\hline Western Europe & $1,044,000$ & 6.6 & 114,000 & 3.8 & 11 \\
\hline Middle East and North Africa & 121,000 & 0.8 & 3500 & 0.1 & 2.9 \\
\hline Pacific Island states and territories & 19,500 & 0.1 & 500 & 0.02 & 2.6 \\
\hline Australia and New Zealand & 173,500 & 1.1 & 2500 & 0.1 & 1.4 \\
\hline Extrapolated global estimates & $15,862,000$ & 100.00 & $2,997,500$ & 100.00 & 19 \\
\hline
\end{tabular}

Data from Mathers et al. (2008), with modification.

\section{Trends in Asia}

In many Asian countries, although new HIV infections peaked around the year 2000 and have declined in the FSW and IDU populations, the initially hidden HIV epidemic in the MSM population has experienced a steady increase (Chan et al. 1998; Colby et al. 2003; Girault et al. 2004; UNAIDS 2010). Consequently, very high HIV prevalences and incidences in MSM have now been reached in many Asian countries, such as Cambodia (9\%), Myanmar $(29 \%)$, India $(5 \%-25 \%)$, China $(1 \%-9 \%$, incidence $3.6 / 100 \mathrm{py})$, and Thailand (17\%$31 \%$, incidence $5.7 / 100$ py) (Ruan et al. 2007; UNAIDS 2010; van Griensven et al. 2010). In China, the proportion of MSM in the annual reported HIV cases increased from $12 \%$ in 2007 to 33\% in 2009 (Mi et al. 2010).

Because of cultural and social pressures, many MSM in Asia are married or otherwise engaged with female partners so as to avoid social stigma and discrimination. For example, approximately one-quarter of the Chinese MSM are married (Tang et al. 2008), and $\sim 30 \%$ of these individuals have sex with a steady female partner (Ruan et al. 2007). In a Bangkok survey of 1121 MSM, 22\% reported having sex with both men and women during the six months before the survey. Of these men, 36\% had engaged in unprotected sex and $17 \%$ were HIV positive (van Griensven et al. 2005). This characteristic of Asian MSM behavior has blurred the line between what, in other parts of the world, are usually distinct HIV-1 epidemics within the MSM community and the general population. MSM in Asia is serving as a bridging group to effectively transmit HIV from high-risk groups to the general population.

IDU is a major route of HIV-1 transmission in this region. Afghanistan and Myanmar are the world's largest opiate- and heroinproducing areas. Whereas one-third of the heroin produced in Afghanistan reaches Europe, one-quarter goes to Central Asia and the Russian Federation. The rest is trafficked to other South and Southeast Asia countries. Most of the heroin produced in Myanmar supplies the local and regional markets, including China, South and Southeast Asia, and Oceania.

\section{Trends in Latin America and the Caribbean}

The HIV prevalence is generally around $1 \%$ in the Caribbean with the notable exception of Cuba, which has a very low prevalence of $0.1 \%$ (UNAIDS 2010). In Latin America and the 
Caribbean, the HIV cases are mostly distributed within discreet MSM, IDU, and FSW networks. The current HIV prevalence in the MSM community remains extremely high in countries such as Peru $(9.8 \%-22.3 \%)$, Argentina (14\%), Uruguay (22\%), Ecuador (15\%), and Columbia (10\%-25\%) (UNAIDS 2008; Cáceres and Mendoza 2009). The world's largest cocaine-producing area is located in the Andean region, covering Columbia, Peru, and Bolivia, and HIV transmission follows the drugtrafficking routes. High HIV prevalences were found in IDUs in Peru $(9.8 \%-22.3 \%)$, Brazil (8\%-65\%), Argentina (14\%-80\%), and Uruguay $(24 \%-76 \%)$ (Hacker et al. 2005; Cáceres and Mendoza 2009).

\section{MOLECULAR EPIDEMIOLOGY}

During the 100 years since HIV-1 was first transmitted to humans, its evolution has resulted in a highly divergent epidemic. The pandemic today is caused by HIV group $M$ viruses, and currently circulating viruses can be categorized into nine distinct clusters, referred to as subtypes or clades (subtypes A$\mathrm{D}, \mathrm{F}-\mathrm{H}, \mathrm{J}$, and $\mathrm{K}$ ), two of which have evolved further into distinct "sub-subtype" lineages known as A1 and A2 for subtype A viruses, and F1 and F2 for subtype F viruses. In addition, lineages have evolved comprising viruses that have been derived through genetic recombination between viruses of different subtypes, which arose when individuals were simultaneously infected with viruses belonging to two different subtypes. Whereas countless unique recombinant viruses have emerged in areas where two or more subtypes cocirculate, when recombinant viruses are discovered to have spread to form their own subepidemics, they are referred to as circulating recombinant forms. There are currently 48 circulating recombinant forms, or CRFs named CRF01 through CRF48 (Los Alamos HIV Sequence Database 2010).

The global spread of HIV has yielded a situation today where the different HIV subtypes and CRFs often have quite distinct geographical distributions. These distributions, along with the numbers of people infected with the different HIV-1M lineages, are illustrated in Figure 2. Equatorial West Africa, the site where HIV has presumably been evolving in humans for the longest period, is also unsurprisingly at the global epicenter of HIV diversity, and here an extraordinary pool of diverse forms exists (Carr et al. 2010).

It is apparent that the global epidemic has been seeded by only a handful of these lineages (Fig. 2). Analysis of HIV-1 sequences is an extremely effective tool for tracking this historical dissemination. Also, HIV evolves rapidly enough that the timescales of viral spread can be traced using the genomic sequences of viruses sampled from the epidemic. Outside of central equatorial Africa, founder events where viruses have moved into new transmission networks and rapidly spread have played a major role in shaping the current diversity of the epidemic (Tebit et al. 2010). The genetic bottlenecks that occur when an entire subepidemic is initiated by a single virus being introduced have resulted in relatively low viral diversities in some regions. There are multiple examples of founder effects, with subtype C being the most successful, globally having founded epidemics in South Africa, India, Ethiopia, and South America (Hermelaar et al. 2006). Other founder effects are seen in Thailand, with subtype B IDU epidemic and CRF01_AE heterosexual epidemic (Korber et al. 2000), in Russia and Eastern Europe with subtype A IDU epidemic (Bobkov et al. 2001), and in China with CRF07_B'C IDU epidemic (Shao et al. 1999; Piyasirisilp et al. 2000; Su et al. 2000; Tee et al. 2008).

Globally, subtype $\mathrm{C}$ is now the most successful of the HIV-1M lineages and today accounts for $>50 \%$ of infections, whereas subtypes $A$ and $\mathrm{B}$ each account for over $10 \%$ of worldwide HIV infections. Subtypes D and G, CRF01_AE, and CRF02_AG account for only between $2 \%$ and $6 \%$ each. Subtypes F, H, J, K, other CRFs, and all other unclassified recombinant forms individually make only a minor contribution to the global HIV population $(<1 \%$ each) but together account for the remaining $15 \%$ of worldwide HIV infections (Hemelaar et al. 2006). The regional distribution of 


\section{$\$_{\mathrm{CSH}}^{\infty}$ Cold Spring Harbor Perspectives in Medicine \\ PERSPECTIVS www.perspectivesinmedicine.org}
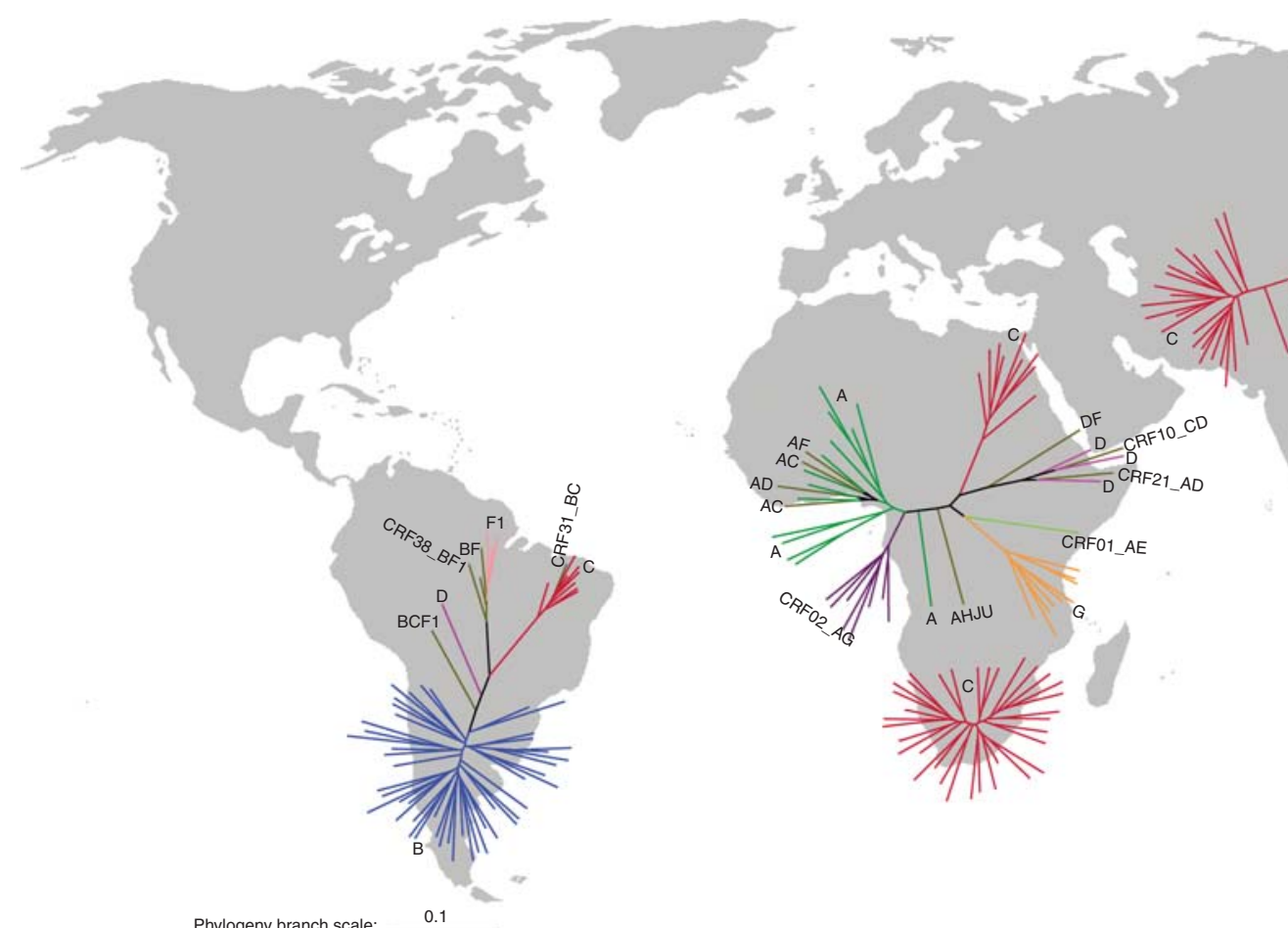

Figure 2. Phylogenetic trees illustrating the diversity of HIV-1 in Africa, Asia, and Latin America with the number of sequences included within each phylogeny roughly proportional to the percentage of subtypes contributing to each epidemic (as described by Hemelaar et al. 2006). The southern African epidemic is illustrated separately from the rest of Africa. Each sequence in the African phylogenies represents 250,000 infections, each sequence in the Asian phylogeny represents 200,000 infections, and each sequence in the Latin American phylogeny represents 26,000 infections. HIV-1 gp160 sequences from Los Alamos HIV database were used (http://www.hiv.lanl.gov/) and branch-length scale is in expected nucleotide substitutions per site. The figure was generated by

Nobubelo Ngandu, University of Cape Town. 
Y. Shao and C. Williamson

different subtypes and CRFs is illustrated in Figure 3.

\section{Tracking the Spread of HIV-1 in Africa}

The oldest HIV-1M sequences that have been analyzed were sampled in 1959 and 1960 from individuals in Central Africa (specifically in Kinshasa in the Democratic Republic of Congo [or DRC]) (Worobey et al. 2008) and appear to be quite closely related to ancestral subtype A and $\mathrm{D}$ viruses. Although all HIV-1M subtypes have been identified in the DRC and Cameroon, subtype A dominates in the DRC, and CRF02_AG dominates in Cameroon (Carr et al. 2010). This AG recombinant, and subtypes A1 and G, are very successful in Western Africa where they today collectively dominate the epidemics in Nigeria, Ghana, Senegal, Mali, and Cote d'Ivoire (Hemelaar et al. 2006).

Outside of West Africa, East Africa has the oldest epidemic that is driven primarily by infections with subtypes A and D and their derived recombinants. Subtype A was likely to have entered East Africa some time shortly after 1950, with subtype D being introduced about ten years later (Vidal et al. 2000; Gray et al. 2009). Today, subtype A dominates in Kenya (Dowling et al. 2002), whereas both subtypes A and D have emerged in Uganda (Herbeck et al. 2007). Tanzania, which lies between the subtype A/D epidemic on its northern border and the subtype $\mathrm{C}$ epidemic on its southern border, is a melting pot of subtype A, C, and, to a lesser extent, $\mathrm{D}$ infections and various recombinant forms. Subtype C accounts for almost all infections in southern Africa.

\section{The Spread of HIV to South America}

In South America, subtype B was initially introduced into MSM transmission networks from Haiti and North America (see Vermund and Leigh-Brown 2011), with subtypes $C$ and F1, and recombinants $\mathrm{BC}$ and $\mathrm{BF} 1$, becoming more dominant later. Although initially it was thought that the South American subtype C epidemic was founded by viruses from Burundi, a country that does not share social, cultural, or economic relations with any South American country, it was later found to be linked to a small subtype C epidemic in the United Kingdom, a country which shares strong ties with Brazil (de Oliveira et al. 2010). Subtype F was thought to be introduced into South America in the late 1970s, and a BF1 recombinant rapidly spread, becoming the dominant virus in Argentina (Aulicino et al. 2007).

\section{The Spread of HIV to Asia and the Pacific Rim}

In Asia, there are four major HIV lineages, including subtypes $\mathrm{C}$ and $\mathrm{B}, \mathrm{CRF} 01 \_\mathrm{AE}$, and CRF07 and 08, which are $\mathrm{B} / \mathrm{C}$ recombinants (Figs. 2 and 4). Subtype C accounts for close to $97 \%$ of infections in India, whereas in Southeast Asia, CRF01_AE accounts for more than $90 \%$ of the infections in Thailand, Vietnam, Cambodia, and Indonesia. In China, CRF07/ 08_B'C, CRF01_AE, and subtype $\mathrm{B}^{\prime}$ viruses are in circulation, whereas in West Asia (mainly Russia and former Soviet states) subtypes A, B, $\mathrm{C}$, and various recombinants all account for similar numbers of infections. Exceptional epidemics in the Asian region occur in the Philippines, where subtype B dominates, and in Pakistan through Central Asia, where subtype A is dominant (Fig. 4).

The Chinese national HIV molecular epidemiology surveys provided an opportunity to view the evolution of the HIV-1 subtypes throughout the country. They showed that the initial epidemic in IDUs in the Yunnan Province bordering Myanmar was dominated by a welldefined lineage of subtype B viruses (known as either the Thai B lineage or subtype $\mathrm{B}^{\prime}$ ) (Ma et al.1990; Shao et al. 1994). This subtype $\mathrm{B}^{\prime}$ was also responsible for a severe epidemic among commercial plasma donors in central China in the mid-1990s, triggered by unsafe practices at that time ( $\mathrm{Li}$ et al. 1997; Cui et al. 2004). In 1992, subtype C viruses, most likely originating from northern India, were detected in IDUs in the Yunnan (Luo et al.1995; Yu et al. 1998; Zhao et al. 1999). In the early 1990s, the Chinese subtype $\mathrm{C}$ and subtype $\mathrm{B}^{\prime}$ lineages recombined with one another to produce CRF07_B'C and 08_B'C (Shao et al. 1999; 

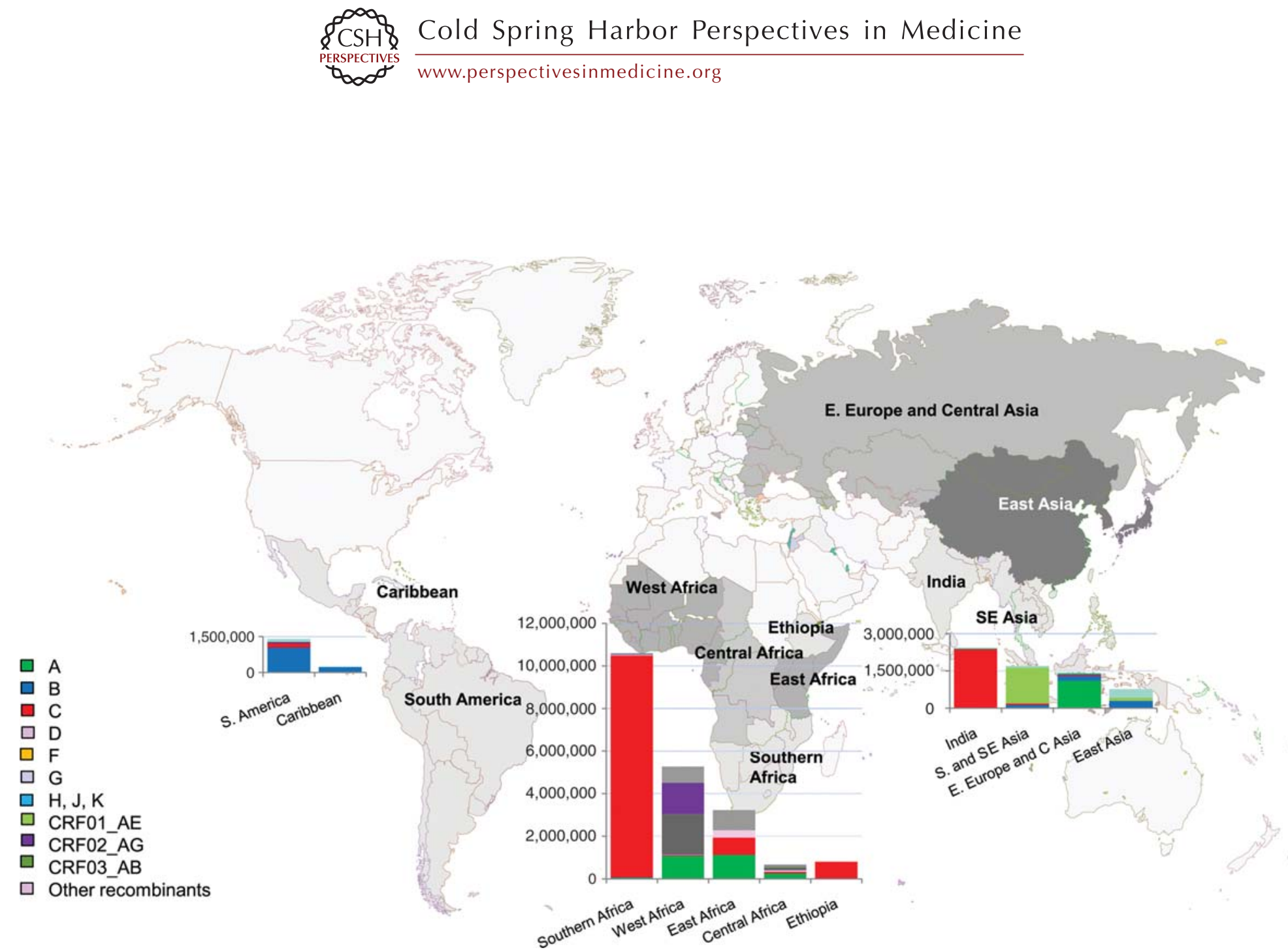

Figure 3. Regional distribution of HIV-1 subtypes and circulating recombinant forms in low- and middle-income countries. Regions comprising different countries are colored in different shades of gray. The size of the bar is proportional to the size of the epidemic (UNAIDS 2010) with the proportion of the subtypes contributing to each epidemic (as calculated by Hemelaar et al. 2006) illustrated as a percentage of the bar. 
$F, G, H, J, K$

CRF01_AE

CRF02_AG

CRF03_AB

CRF07_BC, CRF08_BC

Other recombinants

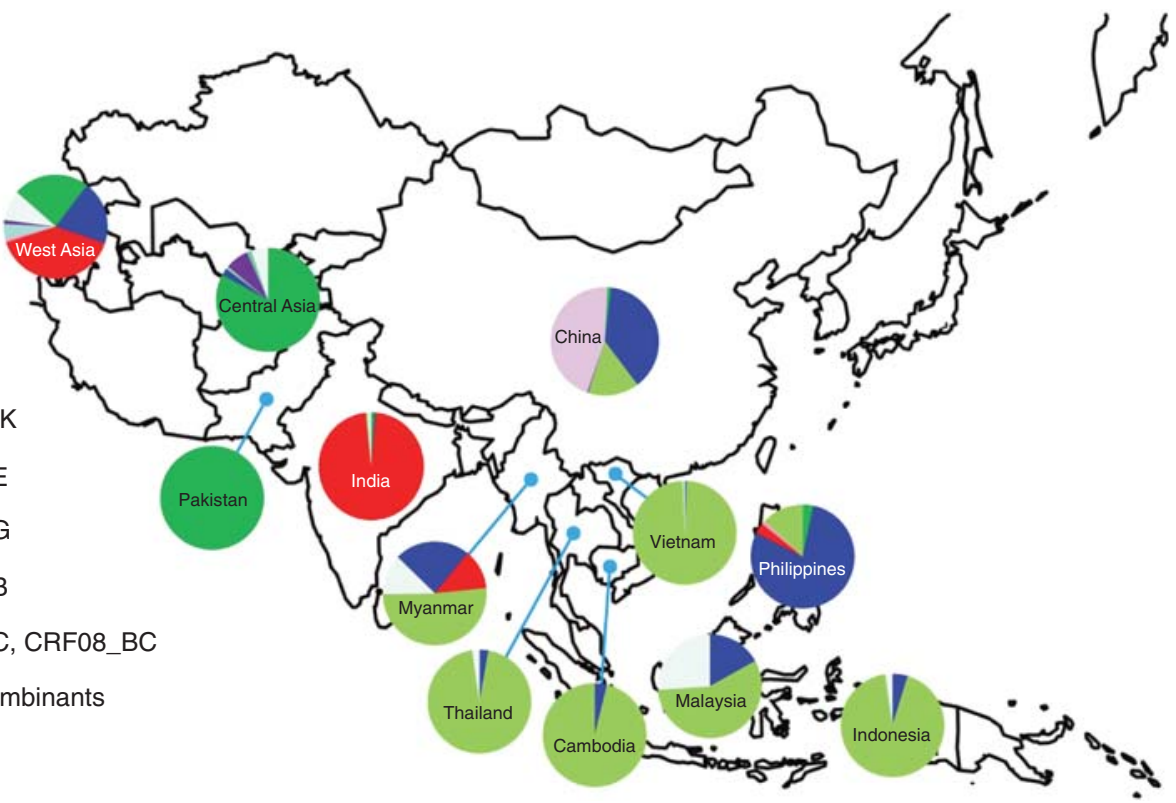

Figure 4. Regional distribution of HIV-1 subtypes and recombinants in Asia. The data of Malaysia, Indonesia, Philippines, Pakistan, Central Asia (including Afghanistan, Kazakstan, and Uzbekistan), and West Asia (including Saudi Arabia, Iran, and Israel) are from the Los Alamos HIV databases (http://www.hiv.lanl.gov/). The data of China, Japan, India, Myanmar, Vietnam, and Thailand are from former studies in the region and estimates based on the unpublished data of research projects (Y Shao, pers. comm.).

Piyasirisilp et al. 2000; Su et al. 2000; Tee et al. 2008). These recombinants were also transmitted among IDUs from Yunnan northward to Sichuan, Qinghai, and Xinjiang region, and eastward to Guangxi Province (Shao et al. 1999; Piyasirisilp et al. 2000; Su et al. 2000). Although CRF01_AE was initially spread in South and Eastern China primarily through heterosexual contacts (Xing et al. 2002; Zhang et al. 2006), it later became one of the dominant HIV-1 strains circulating within the Chinese MSM population living with HIV (Zhang et al. 2007). Within China today, CRF01_AE, CRF07_B'C, and subtype B are the major lineages, with subtype $\mathrm{B}$ decreasing in prominence within this epidemic (Teng et al. 2011).

\section{HIV PATHOGENESIS IN LOW- TO MIDDLE-INCOME COUNTRIES}

It is difficult to directly compare disease progression profiles between lower- and higherincome countries because of the confounding influences of country-to-country differences in both the subtype makeup of circulating viruses, host population differences related to age distributions, gender-dependent infection biases, modes of transmission, and host genetics. Additional confounding factors are the increased frequency in lower-income countries of mixed infections of HIV with other diseases such as tuberculosis, together with decreased access to basic health care such as antibiotics for treating opportunistic infections.

There have been only a few studies that have sought to determine whether there exist subtype-dependent differences in rates of disease progression. In East Africa, where subtypes A and $\mathrm{D}$ are cocirculating, studies have shown that individuals infected with subtype $\mathrm{D}$ viruses tended to progress to AIDS faster than those infected with subtype A viruses (Kaleebu et al. 2002; Kiwanuka et al. 2008). For example, a study by Kiwanuka et al. (2008), involving 350 Ugandan HIV-1 seroconvertors infected with subtype A (15\%), D (59\%), and recombinant forms 
(21\%), found that whereas individuals infected with recombinant viruses had a median time to AIDS of 5.6 years, those infected with subtype $\mathrm{D}$ and $\mathrm{A}$ viruses had a median time to AIDS of 6.5 and 8 years, respectively. Progression to AIDS has been associated with coreceptor switch from CCR5 (R5) to CXCR4 (X4), and one possible explanation for subtype $\mathrm{D}$ viruses being more virulent than subtype Aviruses is that subtype $\mathrm{D}$ viruses are more likely to use CXCR4 as a coreceptor for cellular entry.

In regions of the world where the incidence of HIV is high, individuals are at increased risk of being infected with multiple divergent HIV-1 strains (i.e., diverse members of either the same or different subtypes) (Herbinger et al. 2006). Both coinfection and superinfection have been associated with higher viral loads and increased rates of disease progression (Gottlieb et al. 2004; Grobler et al. 2004). Similarly, in Tanzania where up to $24 \%$ of HIV-positive individuals may be infected with multiple divergent HIV lineages, multiple infections were associated with increased viral loads (Saathoff et al. 2010).

\section{HIV GENETIC DIVERSITY AND DRUG RESISTANCE}

The development of highly effective antiretroviral drugs over the past two decades has saved millions of lives; however, the continuing evolution of resistance to these drugs among circulating HIV variants is of concern and presents a new global challenge. In low- to middle-income countries, alteration of drug combinations to combat multidrug resistance is often not an available treatment option. It is therefore important in these countries that effective HIV drug resistance (HIVDR) surveillance infrastructure is set up, to combat the emergence of HIV lineages that are resistant to multiple antiretrovirals (Bennett et al. 2008).

\section{Surveillance of Transmitted HIVDR in Antiretroviral Treatment-Naïve HIV-1-Infected Individuals}

With increasing numbers of people on antiretroviral therapy, there is also an increased probability of viruses both developing drug resistance mutations and these mutant viruses being transmitted. Individuals infected with viruses carrying multiple drug resistance mutations may have reduced survival prospects, and for this reason, estimates of the rate at which drug resistance mutations are transmitted are a key target metric of the World Health Organization (WHO) HIVDR threshold survey (Bennett et al. 2008). This survey has revealed that fewer than 5\% of HIV transmissions in lowerincome countries such as Malawi (Kamoto et al. 2008), Tanzania, Ethiopia, Swaziland, South Africa, Thailand, and Vietnam involve the transmission of viruses carrying known drug resistance mutations, whereas specific areas of Brazil and China have transmitted drug resistance mutation rates between 5\% and 15\% (Booth et al. 2007; Inocencio et al. 2009; Liao et al. 2010). The prevalence of transmitted HIV drug resistance (TDR) in developing countries is lower than that in developed countries, where in some countries, such as the United States, rates of transmitted drug resistance within newly diagnosed antiretroviral naïve HIV-1-infected individuals are in the range of 15\% (Wheeler et al. 2010). This difference reflects the fact that individuals in higherincome countries have had a longer history of antiretroviral therapy that initially involved single or dual drug treatments (as opposed to the triple drug treatments that are currently preferred).

TDR viruses from higher-income countries may also be spreading to the lower- to middleincome countries. TDR viruses with multidrug resistances to the second-line drugs had been detected in treatment-naïve MSM in Beijing in 2006, before China's national treatment program starting the second-line drug treatment. All of these MSMs with multidrug resistances carried the North American prototype B HIV-1, not the local prevalent B', CRF01_AE and CRF07_B'C viruses (Zhang et al. 2007).

\section{HIVDR in Different Subtypes or CRFs}

The probability of drug resistance mutations arising during antiretroviral treatment increases primarily with the duration of the treatment, and there appears to be no difference between 
lower- and higher-income countries with respect to the rate at which resistance mutations arise in individuals treated with the same drugs (reviewed by Ferradini et al. 2006; Hamers et al. 2008; Kouanfack et al. 2009).

Although many of the drug resistance mutations have been identified in subtype B viruses (the best studied group in this regard) (Kantor et al. 2005), there also exist numerous examples of subtype-specific differences in the spectrum of resistance mutations that naturally arise in response to common ARVs. The reason for this is that evolution of drug resistance often involves more than just a single mutation, and usually a pathway to drug resistance is required whereby accessory mutations enable the emergence of primary resistance mutation by compensating for the damaging effects that resistant mutations may have on viral fitness. For example, subtype $\mathrm{C}$ and CRF07_B'C viruses are predisposed to rapidly acquire the V106M resistance mutation, a well-known efavirenz drug resistance mutation, as the genetic barrier to these viruses acquiring this mutation is substantially lower (need only one nucleotide change) compared with viruses belonging to other subtypes and CRFs (Liao et al. 2007). Because of the similar preexisting background mutations, subtype $\mathrm{C}$ viruses more rapidly developed K65R mutation than other subtypes when exposed to tenofovir (TDF) (Brenner et al. 2006; Doualla-Bell et al. 2006). In some cases the primary drug resistance mutations themselves are already naturally present at relatively high frequencies. For example, the M46I nelfinavir resistance mutation is naturally present in $0.6 \%-1.0 \%$ of CRF01_AE isolates, and this drug should therefore not be widely used on people infected with such viruses (Shafer et al. 2008).

\section{CONSEQUENCES OF HIV GENETIC DIVERSITY ON VACCINE DEVELOPMENT}

A globally effective vaccine would need to protect against the huge variation experienced in different regions of the world, where viruses may differ by as much as 30\% in their envelope protein sequences (Fig. 2) (Gaschen et al. 2002).
Even a vaccine designed to cover a specific region (e.g., a subtype C-specific vaccine in southern Africa) would need to be effective against viruses that are up to $20 \%$ different from one another.

The induction of antiviral neutralizing antibodies is usually the primary aim of vaccines in that this provides the first line of defense blocking incoming virus particles from entering susceptible cells. In early HIV infection, these neutralizing antibodies, directed at the viral Env protein, are very specific and generally only recognize the autologous viruses within that person. However, after many years of infection, some people develop antibodies that recognize a broader range of heterologous viruses, including those that are very different from those which initially generated the antibody response. The production of such broadly acting antibodies is referred to as a broadly cross-reactive neutralizing response (see Overbaugh and Morris 2011). These cross-neutralizing antibodies tend to recognize a diverse array of subtypes, although there is an association between neutralization phenotype and the subtype that induced these antibodies, suggesting that neutralizing epitopes are more conserved within a subtype (Seaman et al. 2010). One of the biggest challenges of current HIV vaccine research is the design of an immunogen which will elicit neutralizing antibodies in vaccinated individuals, which will protect them from infection with the entire range of circulating HIV-1M lineages (Fig. 2) (Kwong et al. 2011).

As an alternative to producing vaccines that will provide antibody-based protection from infection, much effort is being focused on designing vaccines that induce the cellular immune system to attack and kill HIV-infected cells. During normal HIV infections it is the cytotoxic T lymphocytes (CTLs) of the cellular immune system that, at least temporarily, hold the virus in check during the prolonged progression to AIDS. CTLs identify infected cells through the recognition of short linear peptides (usually nine amino acids long) derived from degraded HIV proteins that are presented on the surface of infected cells by human leukocyte antigen (HLA) class I molecules. 
CTL responses tend to recognize peptides matched to the subtype that elicited the response more frequently than to peptides derived from divergent viruses, suggesting that genetic diversity is likely to impact on effectiveness of vaccines (Korber et al. 2009). One strategy for producing a broadly protective CTL-based vaccine is to induce CTL responses with vaccine-derived peptides that differ as little as possible from those of circulating viruses. Probably the best developed version of this strategy to date uses synthetic proteins, called mosaic immunogens, that have been designed in silico to mimic HIV proteins and both maximize CTL epitope coverage and minimize the genetic distance between the immunogens and circulating viruses (Korber et al. 2009). Mosaic immunogens have been found to elicit CTL responses that are of greater magnitude and breadth than those elicited by naturally derived immunogens (Barouch et al. 2010; Santra et al. 2010; Koup and Douek 2011).

\section{CONCLUDING REMARKS}

Low- to middle-income countries continue to be hardest hit by the epidemic, and the health burden imposed by HIV is further exacerbated by poor socioeconomic conditions, the high prevalence of opportunistic infections, poor access to health care, and widespread drug abuse. Further challenges include the stigmatization, and even criminalization, of MSM and IDU in some African and Asian countries, respectively, which makes prevention in these groups difficult. The epidemics in Eastern Europe and Central Asia continue to increase, mainly driven through IDU, whereas in Africa, Latin America, the Caribbean, and most parts of Asia, the epidemics appear to have stabilized. However, within these stabilized epidemics are communities which have frighteningly high epidemic levels, such as urban government antenatal clinics in South Africa where as many as $60 \%$ of pregnant women were HIV-1 positive (Abdool Karim et al. 2010). The HIV epidemic in low- to middle-income countries can only be effectively controlled by combined measures, through social and economic approaches targeting the roots of the epidemic, and with various biomedical prevention, intervention, and treatment.

Molecular epidemiology is an effective tool for tracking the global spread of HIV. The genetic diversity of HIV epidemics in lowerincome countries is greater than that in higherincome countries. This huge diversity, together with high transmission rates and risk of multiple HIV infections, and the occurrence and transmission of drug resistance viruses, will negatively impact pathogenesis and the sustainability of the lifelong antiviral treatment. It is also a major concern that divergent viral lineages, together with new recombinant viruses, will undermine vaccine development efforts. A vaccine against HIV-1 would be the most effective method of controlling this pandemic. Lowto middle-income countries can make a major contribution to these efforts as their high incidences of infection make them ideal locations for prevention and treatment researches, as well as for phase III HIV vaccine trials. It is hoped that closer global cooperation from upstream basic research to downstream clinical trials will greatly speed better intervention and treatment strategies as well as the ultimate production of a successful AIDS vaccine (Kaleebu et al. 2008; Kent et al. 2010).

\section{ACKNOWLEDGMENTS}

We thank Min Wei for helping look for background materials, Lingjie Liao, Xiang $\mathrm{He}$, and Tao Teng for searching and arranging the references, Yi Feng and Qifne Sun for generating the tables and some of the figures, Nobubelo Ngandu for generating phylogenetic trees to illustrate global diversity, Debbie Stewart for her help with figures and database searches, and Darren Martin for review and comment.

\section{REFERENCES}

${ }^{*}$ Reference is also in this collection.

Abdool Karim Q, Kharsany AB, Frohlich JA, Werner L, Mashego M, Mlotshwa M, Madlala BT, Ntombela F, Abdool Karim SS. 2010. Stabilizing HIV prevalence masks high HIV incidence rates amongst rural and urban 
women in KwaZulu-Natal, South Africa. Int J Epidemiol doi: $10.1093 /$ ije/dyq176.

Aulicino PC, Holmes EC, Rocco C, Mangano A, Sen L. 2007. Extremely rapid spread of human immunodeficiency virus type $1 \mathrm{BF}$ recombinants in Argentina. J Virol 81: 427-429.

Auvert B, Taljaard D, Lagarde E, Sobngwi-Tambekou J, Sitta R, Puren A. 2005. Randomized, controlled intervention trial of male circumcision for reduction of HIV infection risk: The ANRS 1265 trial. PLoS Med 2: e298. doi: 10.1371/journal.pmed.0020298.

Barouch DH, O'Brien KL, Simmons NL, King SL, Abbink P, Maxfield LF, Sun YH, La Porte A, Riggs AM, Lynch DM, et al. 2010. Mosaic HIV-1 vaccines expand the breadth and depth of cellular immune responses in rhesus monkeys. Nat Med 16: 319-323.

Bennett DE, Bertagnolio S, Sutherland D, Gilks CF. 2008 The World Health Organization's global strategy for prevention and assessment of HIV drug resistance. Antivir Ther 13: $1-13$.

Bobkov A, Kazennova E, Khanina T, Bobkova M, Selimova L, Kravchenko A, Pokrovsky V, Weber J. 2001. An HIV type 1 subtype A strain of low genetic diversity continues to spread among injecting drug users in Russia: Study of the new local outbreaks in Moscow and Irkutsk. AIDS Res Hum Retroviruses 17: 257-261.

Booth CL, Geretti AM. 2007. Prevalence and determinants of transmitted antiretroviral drug resistance in HIV-1 infection. J Antimicrob Chemother 59: 1047-1056.

Brenner BG, Oliveira M, Doualla-Bell F, Moisi DD, Ntemgwa M, Frankel F, Essex M, Wainberg MA. 2006. HIV-1 subtype C viruses rapidly develop K65R resistance to tenofovir in cell culture. AIDS 20: F9-F13.

Cáceres CF, Mendoza W. 2009. The national response to the HIV/AIDS epidemic in Peru: Accomplishments and gaps-A review. J Acquir Immune Defic Syndr 51: S60-S66.

Carr JK, Wolfe ND, Torimiro JN, Tamoufe U, MpoudiNgole E, Eyzaguirre L, Birx DL, McCutchan FE, Burke DS. 2010. HIV-1 recombinants with multiple parental strains in low-prevalence, remote regions of Cameroon: Evolutionary relics? Retrovirology 7: 39.

Chan R, Kavi AR, Carl G, Khan S, Oetomo D, Tan ML, Brown T. 1998. HIV and men who have sex with men: Perspectives from selected Asian countries. AIDS 12: 59-68.

China Ministry of Health, UNAIDS, WHO. 2009. Estimates for the HIV/AIDS epidemic in China. http://www. unaids.org.cn/en/index/Document_view.asp?id=413.

Cui W, Xing H, Wang Zh, Huang H, Li H, Ma P, Xue X, Wei M, Zhu X, Shao Y. 2004. Study on subtype and sequence of the C2-V3 region of env gene among HIV-1 strains in Henan Province. Chin J AIDS STD 10: 403-406.

Colby DJ. 2003. HIV knowledge and risk factors among men who have sex with men in Ho Chi Minh City, Vietnam. J Acquir Immune Defic Syndr 32: 80-85.

Crofts N, Reid G, Deany P. 1998. Injecting drug use and HIV infection in Asia. AIDS 12: 69-78.

De Oliveira T, Pillay D, Gifford RJ. UK Collaborative Group on HIV Drug Resistance. 2010. The HIV-1 subtype $\mathrm{C}$ epidemic in South America is linked to the
United Kingdom. PLoS One 19: 9311. doi: 10.1371/ journal.pone.0009311.

Dore GJ, Kaldor JM, Ungchusak K, Mertens TE. 1996. Epidemiology of HIV and AIDS in the Asia-Pacific region. Med J Aust 165: 494-498.

Doualla-Bell F, Avalos A, Brenner B, Gaolathe T, Mine M, Gaseitsiwe S, Oliveira M, Moisi D, Ndwapi N, Moffat $\mathrm{H}$, et al. 2006. High prevalence of the K65R mutation in human immunodeficiency virus type 1 subtype $\mathrm{C}$ isolates from infected patients in Botswana treated with didanosine-based regimens. Antimicrob Agents Chemother 50: 4182-4185.

Dowling WE, Kim B, Mason CJ, Wasunna KM, Alam U, Elson L, Birx DL, Robb ML, McCutchan FE, Carr JK. 2002. Forty-one near full-length HIV-1 sequences from Kenya reveal an epidemic of subtype A and A-containing recombinants. AIDS 16: 1809-1820.

Estebanez P, Fitch K, Najera R. 1993. HIV and female sex workers. Bull World Health Organ 71: 397-412.

Ferradini L, Jeannin A, Pinoges L, Izopet J, Odhiambo D, Mankhambo L, Karungi G, Szumilin E, Balandine S, Fedida G, et al. 2006. Scaling up of highly active antiretroviral therapy in a rural district of Malawi: An effectiveness assessment. Lancet 367: 1335-1342.

Gaschen B, Taylor J, Yusim K, Foley B, Gao F, Lang D, Novitsky V, Haynes B, Hahn BH, Bhattacharya T, et al. 2002. Diversity considerations in HIV-1 vaccine selection. Science 296: 2354-2360.

Girault P, Saidel T, Song N, de Lind Van Wijngaarden JW, Dallabetta G, Stuer F, Mills S, Or V, Grosjean P, Glaziou P, et al. 2004. HIV, STIs, and sexual behaviors among men who have sex with men in Phnom Penh, Cambodia. AIDS Educ Prev 16: 31-44.

Gottlieb GS, Nickle DC, Jensen MA, Wong KG, Grobler J, Li F, Liu SL, Rademeyer C, Learn GH, Karim SS, et al. 2004. Dual HIV-1 infection associated with rapid disease progression. Lancet 363: 619-622.

Gouws E, Abdool Karim Q. 2010. HIV infection in South Africa: The evolving epidemic. In HIV/AIDS in South Africa, 2nd ed., pp. 55-73. Cambridge University Press, Cambridge.

Gray RH, Kigozi G, Serwadda D, Makumbi F, Watya S, Nalugoda F, Kiwanuka N, Moulton LH, Chaudhary MA, Chen MZ, et al. 2007. Male circumcision for HIV prevention in men in Rakai, Uganda: A randomised trial. Lancet 369: 657-666.

Gray RR, Tatem AJ, Lamers S, Hou W, Laeyendecker O, Serwadda D, Sewankambo N, Gray RH, Wawer M, Quinn TC, et al. 2009. Spatial phylodynamics of HIV-1 epidemic emergence in East Africa. AIDS 23: F9-F17.

Gregson S, Nyamukapa CA, Garnett GP, Mason PR, Zhuwau T, Caraël M, Chandiwana SK, Anderson RM. 2002. Sexual mixing patterns and sex-differentials in teenage exposure to HIV infection in rural Zimbabwe. Lancet 359: 1896-1903.

Grobler J, Gray CM, Rademeyer C, Seoighe C, Ramjee G, Karim SA, Morris L, Williamson C. 2004. Incidence of HIV-1 dual infection and its association with increased viral load set point in a cohort of HIV-1 subtype Cinfected female sex workers. J Infect Dis 190: 1355-1359.

Gupta RK, Chrystie IL, O’Shea S, Mullen JE, Kulasegaram R, Tong CY. 2005. K65R and Y181C are less prevalent in 
HAART-experienced HIV-1 subtype A patients. AIDS 19: 1916-1919.

Hacker MA, Malta M, Enriquez M, Bastos FI. 2005. Human immunodeficiency virus, AIDS, and drug consumption in South America and the Caribbean: Epidemiological evidence and initiatives to curb the epidemic. Rev Panam Salud Publica 18: 303-313.

Hamers RL, Derdelinckx I, van Vugt M, Stevens W, Rinke de Wit TF, Schuurman R. 2008. The status of HIV-1 resistance to antiretroviral drugs in sub-Saharan Africa. Antivir Ther 13: 625-639.

Hemelaar J, Gouws E, Ghys PD, Osmanov S. 2006. Global and regional distribution of HIV-1 genetic subtypes and recombinants in 2004. AIDS 20: W13-W23.

Herbeck JT, Lyagoba F, Moore SW, Shindo N, Biryahwaho B, Kaleebu P, Mullins JI. 2007. Prevalence and genetic diversity of HIV type 1 subtypes A and D in women attending antenatal clinics in Uganda. AIDS Res Hum Retroviruses 23: $755-760$.

Herbinger KH, Gerhardt M, Piyasirisilp S, Mloka D, Arroyo MA, Hoffmann O, Maboko L, Birx DL, Mmbando D, McCutchan FE, et al. 2006. Frequency of HIV type 1 dual infection and HIV diversity: Analysis of low- and high-risk populations in Mbeya Region, Tanzania. AIDS Res Hum Retroviruses 22: 599-606.

Inocencio LA, Pereira AA, Sucupira MC, Fernandez JC, Jorge CP, Souza DF, Fink HT, Diaz RS, Becker IM, Suffert TA, et al. 2009. Brazilian network for HIV drug resistance surveillance: A survey of individuals recently diagnosed with HIV. J Int AIDS Soc 12: 20.

Kaleebu P, French N, Mahe C, Yirrell D, Watera C, Lyagoba F, Nakiyingi J, Rutebemberwa A, Morgan D, Weber J, et al. 2002. Effect of human immunodeficiency virus (HIV) type 1 envelope subtypes $A$ and $D$ on disease progression in a large cohort of HIV-1-positive persons in Uganda. J Infect Dis 185: 1244-1250.

Kaleebu P, Abimiku A, El-Halabi S, Koulla-Shiro S, Mamotte N, Mboup S, Mugerwa R, Nkengasong J, ToureKane C, Tucker T, et al. 2008. African AIDS vaccine programme for a coordinated and collaborative vaccine development effort on the continent. PLoS Med 5: e236. doi: 10.1371/journal.pmed.0050236.

Kamoto K, Aberle-Grasse J. 2008. Surveillance of transmitted HIV drug resistance with the World Health Organization threshold survey method in Lilongwe, Malawi. Antivir Ther 13: 83-87.

Kantor R, Katzenstein DA, Efron B, Carvalho AP, Wynhoven B, Cane P, Clarke J, Sirivichayakul S, Soares MA, Snoeck J, et al. 2005. Impact of HIV-1 subtype and antiretroviral therapy on protease and reverse transcriptase genotype: Results of a global collaboration. PLoS Med 2: e112. doi: 10.1371/journal.pmed.0020112.

Keele BF, Van Heuverswyn F, Li Y, Bailes E, Takehisa J, Santiago ML, Bibollet-Ruche F, Chen Y, Wain LV, Liegeois F, et al. 2006. Chimpanzee reservoirs of pandemic and nonpandemic HIV-1. Science 313: 523-526.

Kent SJ, Cooper DA, Chhi Vun M, Shao Y, Zhang L, Ganguly N, Bela B, Tamashiro H, Ditangco R, Rerks-Ngarm S, et al. 2010. AIDS vaccine for Asia network (AVAN): Expanding the regional role in developing HIV vaccines. PLoS Med 7: e1000331. doi: 10.1371/journal.pmed.1000331.
Kiwanuka N, Laeyendecker O, Robb M, Kigozi G, Arroyo M, McCutchan F, Eller LA, Eller M, Makumbi F, Birx D, et al. 2008. Effect of human immunodeficiency virus type 1 (HIV-1) subtype on disease progression in persons from Rakai, Uganda, with incident HIV-1 infection. J Infect Dis 197: 707-713.

Korber B, Muldoon M, Theiler J, Gao F, Gupta R, Lapedes A, Hahn BH, Wolinsky S, Bhattacharya T. 2000. Timing the ancestor of the HIV-1 pandemic strains. Science 288: 1789-1796.

Korber BT, Letvin NL, Haynes BF. 2009. T-cell vaccine strategies for human immunodeficiency virus, the virus with a thousand faces. J Virol 83: 8300-8314.

Kouanfack C, Montavon C, Laurent C, Aghokeng A, Kenfack A, Bourgeois A, Koulla-Shiro S, Mpoudi-Ngole E, Peeters M, Delaporte E. 2009. Low levels of antiretroviralresistant HIV infection in a routine clinic in Cameroon that uses the World Health Organization (WHO) public health approach to monitor antiretroviral treatment and adequacy with the WHO recommendation for secondline treatment. Clin Infect Dis 48: 1318-1322.

* Koup RA, Douek DC. 2011. Vaccine design for CTL responses. Cold Spring Harb Perspect Med doi: 10.1101/ cshperspect.a007252.

* Kwong PD, Mascola JR, Nabel GJ. 2011. Rational design of vaccines to elicit broadly neutralizing antibodies to HIV-1. Cold Spring Harb Perspect Med doi: 10.1101/ cshperspect.a007278.

Li Y, Shao Y, Luo X, Su L, Zhang L, Chen J, Fang Y, Yaun J, Zhang Y, Chen H, et al. 1997. Subtype and sequence analysis of the $\mathrm{C} 2-\mathrm{V} 3$ region of gp120 genes among HIV-1 strains in Hubei province. Chin J Epidemiol 18: 217-219.

Li Y, Uenishi R, Hase S, Liao H, Li XJ, Tsuchiura T, Tee KK, Pybus OG, Takebe Y. 2010. Explosive HIV-1 subtype B' epidemics in Asia driven by geographic and risk group founder events. Virology 402: 223-227.

Liao L, Xing H, Li X, Ruan Y, Zhang Y, Qin G, Shao Y. 2007. Genotypic analysis of the protease and reverse transcriptase of HIV type 1 isolates from recently infected injecting drug users in western China. AIDS Res Hum Retroviruses 23: 1062-1065.

Liao L, Xing H, Shang H, Li J, Zhong P, Kang L, Cheng H, Si X, Jiang S, Li X, et al. 2010. The prevalence of transmitted antiretroviral drug resistance in treatment-naive HIV-infected individuals in China. J Acquir Immune Defic Syndr 53: S10-S14.

Los Alamos HIV Sequence Database. 2010. Overview of the subtypes of primate immunodeficiency viruses. http://www.hiv.lanl.gov/content/sequence/HelpDocs/ subtypes.html.

Luo CC, Tian C, Hu DJ, Kai M, Dondero T, Zheng X. 1995. HIV-1 subtype C in China. Lancet 345: 1051-1052.

Ma Y, Li Z, Zhao S. 1990. HIV infected people were first identified in intravenous drug users in China. Chin J Epidemiol 11: 184-185.

Mathers BM, Degenhardt L, Phillips B, Wiessing L, Hickman M, Strathdee SA, Wodak A, Panda S, Tyndall M, Toufik A, et al. 2008. Global epidemiology of injecting drug use and HIV among people who inject drugs: A systematic review. Lancet 372: 1733-1745. 
Mi G, Wu Z. 2010. A review of studies on sero-sorting among HIV positive men who have sex with men. Chin J AIDS STD 16: 201-203.

Ott MQ, Bärnighausen T, Tanser F, Lurie MN, Newell ML. 2011. Age-gaps in sexual partnerships: Seeing beyond "sugar daddies." AIDS 25: 861-863.

* Overbaugh J, Morris L. 2011. The antibody response against HIV-1. Cold Spring Harb Perspect Med doi: 10.1011/ cshperspect.a007039.

PAHO, WHO, UNAIDS. 2001. Monitoring the AIDS Epidemic (MAP). HIV and AIDS in the Americas: An epidemic with many faces. http://www.who.int/hiv/ strategic/pubrio00/en/index.html.

Pereyra F, Jia X, McLaren PJ, Telenti A, de Bakker PI, Walker BD et al.. 2010. The major genetic determinants of HIV-1 control affect HLA class I peptide presentation. International HIV controllers study. Science 330: 1551-1557.

Phanuphak P, Locharernkul C, Panmuong W, Wilde H. 1985. A report of three cases of AIDS in Thailand. Asian Pac J Allergy Immunol 3: 195-199.

Piot P, Quinn TC, Taelman H, Feinsod FM, Minlangu KB, Wobin O, Mbendi N, Mazebo P, Ndangi K, Stevens W, et al.1984. Acquired immunodeficiency syndrome in a heterosexual population in Zaire. Lancet 2: 65-69.

Piyasirisilp S, McCutchan FE, Carr JK, Sanders-Buell E, Liu W, Chen J, Wagner R, Wolf H, Shao Y, Lai S, et al. 2000. A recent outbreak of human immunodeficiency virus type 1 infection in southern China was initiated by two highly homogeneous, geographically separated strains, circulating recombinant form $\mathrm{AE}$ and a novel $\mathrm{BC}$ recombinant. J Virol 74: 11286-11295.

Powers KA, Ghani AC, Miller WC, Hoffman IF, Pettifor AE, Kamanga G, Martinson FE, Cohen MS. 2011. The role of acute and early HIV infection in the spread of HIV and implications for transmission prevention strategies in Lilongwe, Malawi: A modelling study. Lancet 378: 256-268.

Powers KA, Poole C, Pettifor AE, Cohen MS. 2008. Rethinking the heterosexual infectivity of HIV-1: A systematic review and meta-analysis. Lancet Infect Dis 8: 553-563.

Ruan Y, Li D, Li X, Qian HZ, Shi W, Zhang X, Yang Z, Zhang X, Wang C, Liu Y, et al. 2007. Relationship between syphilis and HIV infections among men who have sex with men in Beijing, China. Sex Transm Dis 34: 592-597.

Saathoff E, Pritsch M, Geldmacher C, Hoffmann O, Koehler RN, Maboko L, Maganga L, Geis S, McCutchan FE, Kijak $\mathrm{GH}$, et al. 2010. Viral and host factors associated with the HIV-1 viral load setpoint in adults from Mbeya Region, Tanzania. J Acquir Immune Defic Syndr 54: 324-330.

Santra S, Liao HX, Zhang R, Muldoon M, Watson S, Fischer W, Theiler J, Szinger J, Balachandran H, Buzby A, et al. 2010. Mosaic vaccines elicit $\mathrm{CD}^{+} \mathrm{T}$ lymphocyte responses that confer enhanced immune coverage of diverse HIV strains in monkeys. Nat Med 16: 324-328.

Seaman MS, Janes H, Hawkins N, Grandpre LE, Devoy C, Giri A, Coffey RT, Harris L, Wood B, Daniels MG, et al. 2010. Tiered categorization of a diverse panel of HIV-1 Env pseudoviruses for assessment of neutralizing antibodies. J Virol 84: 1439-1452.

Serwadda D, Mugerwa RD, Sewankambo NK, Lwegaba A, Carswell JW, Kirya GB, Bayley AC, Downing RG, Tedder RS, Clayden SA, et al. 1985. Slim disease: A new disease in
Uganda and its association with HTLV-III infection. Lancet 2: 849-852.

Shafer RW, Rhee SY, Bennett DE. 2008. Consensus drug resistance mutations for epidemiological surveillance: Basic principles and potential controversies. Antivir Ther 13: 59-68.

Shao Y, Zhao Q, Wang B, Chen Zh, Su L, Zeng Y, Wolf H. 1994. Sequence analysis of HIV env genes among HIV infected drug injecting users in Dehong epidemic area of Yunnan Province, China. Chin J Virol 10: 291-299 (in Chinese)

Shao Y, Zhao F, Yang W, XC Gong. 1999. The identification of recombinant HIV-1 strains in IDUs in southwest and northwest China. Chin J Exp Clin Virol 13: 109-112 (in Chinese).

Simoes EA, Babu PG, John TJ, Nirmala S, Solomon S, Lakshminarayana CS, Quinn TC. 1987. Evidence for HTLV-III infection in prostitutes in Tamil Nadu. (India). Indian J Med Res 85: 335-338.

Steffenson AE, Pettifor AE, Seage GR III, Rees HV, Cleary PD. 2011. Concurrent sexual partnerships and human immunodeficiency virus risk among South African youth. Sex Transm Dis 38: 459-466.

Su L, Graf M, Zhang Y, von Briesen H, Xing H, Kostler J, Melzl H, Wolf H, Shao YM, Wagner R. 2000. Characterization of a virtually full-length human immunodeficiency virus type 1 genome of a prevalent intersubtype (C/B) recombinant strain in China. J Virol 74: 11367-11376.

Tang WM, Ding JP, Yan HJ, Xuan XP, Yang HT, Zhao JK. 2008. Sexual behaviors and HIV/syphilis infection among men who have sex with men: A meta analysis of data collected between 2001 and 2006 in the Chinese mainland. Chin J AIDS STD 14: 471-488.

Taylor BS, Sobieszczyk ME, McCutchan FE, Hammer SM. 2008. The challenge of HIV-1 subtype diversity. N Engl J Med 358: 1590-1602.

Tebit DM, Arts EJ. 2010. Tracking a century of global expansion and evolution of HIV to drive understanding and to combat disease. Lancet Infect Dis 1: 45-56.

Tee KK, Pybus OG, Li XJ, Han X, Shang H, Kamarulzaman A, Takebe Y. 2008. Temporal and spatial dynamics of human immunodeficiency virus type 1 circulating recombinant forms 08_BC and 07_BC in Asia.J Virol 82: 9206-9215.

Teng T, Shao Y. 2011. Scientific approaches to AIDS prevention and control in China. Adv Dent Res 23: 10-12.

Tully DC, Wood C. 2010. Chronology and evolution of the HIV-1 subtype C epidemic in Ethiopia. AIDS 24: 1577-1582.

Xing H, Pan P, Su L, Fan X, Feng Y, Qiang L, Shao Y. 2002. Molecular epidemiological study of a HIV-1 strain of subtype E in China between 1996 and 1998. Chin J STD/AIDS Prev Cont 8: 200-203.

Xu F, Kilmarx PH, Supawitkul S, Yanpaisarn S, Limpakarnjanarat K, Manopaiboon C, Korattana S, Mastro TD, StLouis ME. 2000. HIV-1 seroprevalence, risk factors, and preventive behaviors among women in northern Thailand. J Acquir Immune Defic Syndr 25: 353-359.

UNAIDS. 2008. UNAIDS report on the global HIV epidemic: 2008. http://www.unaids.org/GlobalReport/. 
UNAIDS. 2010. UNAIDS report on the global HIV epidemic: 2010. http://www.unaids.org/GlobalReport/.

UNODC. 2010. The global heroin market. World Drug Report 2010, pp. 37-63.

Van de Perre P, Rouvroy D, Lepage P, Bogaerts J, Kestelyn P, Kayihigi J, Hekker AC, Butzler JP, Clumeck NA. 1984. Acquired immunodeficiency syndrome in Rwanda. Lancet 2: 62-65.

van Griensven F, Thanprasertsuk S, Jommaroeng R, Mansergh G, Naorat S, Jenkins RA, Ungchusak K, Phanuphak P, Tappero JW, Bangkok MSM Study Group. 2005. Evidence of a previously undocumented epidemic of HIV infection among men who have sex with men in Bangkok, Thailand. AIDS 19: 521-526.

van Griensven F, Varangrat A, Wimonsate W, Tanpradech S, Kladsawad K, Chemnasiri T, Suksripanich O, Phanuphak P, Mock P, Kanggarnrua K, et al. 2010. Trends in HIV prevalence, estimated HIV incidence and risk behavior among men who have sex with men in Bangkok, Thailand, 2003-2007. J Acquir Immune Defic Syndr 53: 234-249.

* Vermund ST, Leigh-Brown A. 2011. The HIV epidemic: High-income countries. Cold Spring Harb Perspect Med doi: 10.1101/cshperspect.a007195.

Vidal N, Peeters M, Mulanga-Kabeya C, Nzilambi N, Robertson D, Ilunga W, Sema H, Tshimanga K, Bongo B, Delaporte E. 2000. Unprecedented degree of human immunodeficiency virus type 1 (HIV-1) group M genetic diversity in the Democratic Republic of Congo suggests that the HIV-1 pandemic originated in Central Africa. $J$ Virol 74: 10498-10507.

Wheeler WH, Ziebell RA, Zabina H, Pieniazek D, Prejean J, et al. 2010. Prevalence of transmitted drug resistance associated mutations and HIV-1 subtypes in new HIV-1 diagnoses, U.S.-2006. AIDS 24: 1203-1212.
Xin R, He X, Xing H, Sun F, Ni M, Zhang Y, Meng Z, Feng Y, Liu S, Wei J, et al. 2009. Genetic and temporal dynamics of human immunodeficiency virus type 1 CRF07_BC in Xinjiang, China. J Gen Virol 90: 1757-1761.

WHO. 1998. Fifty years of WHO in the Western Pacific Region, Chapter 26. Sexually transmitted diseases, including HIV/AIDS, pp. 245-259. http://www.wpro. who.int/NR/rdonlyres/3E44D634-C0F9-480C-B6C21C418AE8F3A0/0/chapter26.pdf.

Worobey M, Gemmel M, Teuwen DE, Haselkorn T, Kunstman K, Bunce M, Muyembe JJ, Kabongo JM, Kalengayi RM, Van Marck E, et al. 2008. Direct evidence of extensive diversity of HIV-1 in Kinshasa by 1960. J Nature 455: 661-664.

Yu XF, Chen J, Shao Y, Beyrer C, Lai S. 1998. Two subtypes of HIV-1 among injection-drug users in southern China. Lancet 351: 1250.

Zeng Y, Fan J, Zhang Q, Wang P, Tang D, Zhon S, Zheng X, Liu D. 1986. Detection of antibody to LAV/HTLV-III in sera from hemophiliacs in China. AIDS Res 2: S147-S149.

Zhang Y, Lu L, Ba L, Liu L, Yang L, Jia M, Wang H, Fang Q, Shi Y, Yan W, et al. 2006. Dominance of HIV-1 subtype CRF01_AE in sexually acquired cases leads to a new epidemic in Yunnan province of China. PLoS Med 3: e443. doi: 10.1371/journal.pmed.0030443.

Zhang X, Li Sh, Li X, Li X, Xu J, Li D, Ruan Y, Xing H, Zhang X, Shao Y. 2007. Characterization of HIV-1 subtypes and viral antiretroviral drug resistance in men who have sex with men in Beijing, China. AIDS 21: S59-S66.

Zhao F, Shao Y, Duan Y, Chen X, Zhao Q, Su L, Guan Y, Zeng Y, Wolf H. 1999. Sequence analysis of human immunodeficiency virus type 1 tat gene among the long term HIV infected non-progressor in Yunnan province. Chin J Exp Clin Virol 13: 37-40. 


\section{$\&_{\mathrm{CSH}}^{\infty} \&$ Cold Spring Harbor

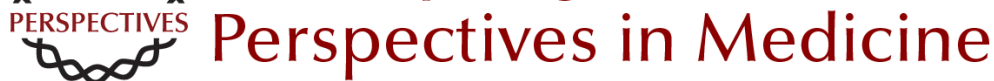

\section{The HIV-1 Epidemic: Low- to Middle-Income Countries}

Yiming Shao and Carolyn Williamson

Cold Spring Harb Perspect Med 2012; doi: 10.1101/cshperspect.a007187 originally published online December 22, 2011

\section{Subject Collection HIV}

HIV Pathogenesis: Dynamics and Genetics of

Viral Populations and Infected Cells John Coffin and Ronald Swanstrom

Human Immunodeficiency Virus Vaccine Trials Robert J. O'Connell, Jerome H. Kim, Lawrence Corey, et al.

HIV Transmission George M. Shaw and Eric Hunter

Novel Cell and Gene Therapies for HIV James A. Hoxie and Carl H. June

Behavioral and Biomedical Combination Strategies for HIV Prevention Linda-Gail Bekker, Chris Beyrer and Thomas C. Quinn

HIV-1 Assembly, Budding, and Maturation Wesley I. Sundquist and Hans-Georg Kräusslich

HIV-1 Assembly, Budding, and Maturation Wesley I. Sundquist and Hans-Georg Kräusslich

Lessons in Nonhuman Primate Models for AIDS Vaccine Research: From Minefields to Milestones Jeffrey D. Lifson and Nancy L. Haigwood
HIV-1 Pathogenesis: The Virus

Ronald Swanstrom and John Coffin

The T-Cell Response to HIV

Bruce Walker and Andrew McMichael

HIV-1 Reverse Transcription Wei-Shau Hu and Stephen H. Hughes

HIV Pathogenesis: The Host A.A. Lackner, Michael M. Lederman and Benigno Rodriguez

HIV: Cell Binding and Entry Craig B. Wilen, John C. Tilton and Robert W. Doms

Innate Immune Control of HIV Mary Carrington and Galit Alter

HIV DNA Integration

Robert Craigie and Frederic D. Bushman

HIV-1-Related Central Nervous System Disease: Current Issues in Pathogenesis, Diagnosis, and Treatment Serena Spudich and Francisco González-Scarano

For additional articles in this collection, see http://perspectivesinmedicine.cshlp.org/cgi/collection/ 